\title{
Heterogeneity of antimitochondrial antibodies with the M2-M4 pattern by immunofluorescence as assessed by Western immunoblotting and enzyme linked immunosorbent assay
}

\author{
M FUSCONI, I GHADIMINEJAD, F B BIANCHI, H BAUM, \\ G F BOTTAZZO, AND E PISI \\ From the Instituto di Clinica Medica Generale e Terapia Medica, Cattedre di Clinica Medica II e Semeiotica \\ Medica, University of Bologna, Bologna, Italy, Biochemistry Department, King's College, University of \\ London, London, and Immunology Department, The Middlesex Hospital Medical School, London
}

SUMMARY Seventy seven sera with antimitochondrial antibody exhibiting the M2-M4 pattern in immunofluorescence (56 from primary biliary cirrhosis (PBC), 21 from non-primary biliary cirrhosis patients) were studied by the combined use of Western immunoblotting with beef heart mitochondria and an enzyme linked immunosorbent assay (ELISA) with beef heart submitochondrial particles. Forty seven sera (10 without autoantibodies and 37 with different autoantibodies) were included as controls. By immunoblotting, seven mitochondrial peptides reacting with antimitochondrial antibody positive sera were detected. These were of molecular weight $74 \mathbf{~ k D}$, $58 \mathrm{kD}, 55 \mathrm{kD}, 52 \mathrm{kD}, 51 \mathrm{kD}, 46 \mathrm{kD}$, and $43 \mathrm{kD}$. All primary biliary cirrhosis sera and $71 \%$ of antimitochondrial antibody-positive non-primary biliary cirrhosis sera reacted with one or more of these peptides, while none of the 47 antimitochondrial antibody negative sera reacted in immunoblotting. The $74 \mathrm{kD}$ band was the most frequently detected (84\% of primary biliary cirrhosis and $57 \%$ of non-primary biliary cirrhosis cases). All the primary biliary cirrhosis sera which failed to react with this peptide, showed a positive reaction with that of molecular weight $52 \mathrm{kD}$. 67/77 (87\%) immunofluorescence antimitochondrial antibody positive sera reacted in the ELISA test (93\% of primary biliary cirrhosis and $71 \%$ of non-primary biliary cirrhosis cases). All the 47 immunofluorescence antimitochondrial antibody negative sera were confirmed negative by ELISA. The ELISA values correlated with the immunofluorescence titres $(p<0 \cdot 05)$. By comparison of the results obtained by these two techniques, it emerged that the ELISA test (using our preparation of submitochondrial particles) was not able to detect the antibody directed against the mitochondrial peptide of $52 \mathrm{kD}$, which thus seems to be different from the other specificities.

Antimitochondrial antibodies are a broad family of autoantibodies found in sera of patients with different diseases. The antimitochondrial antibody specificities and their occurrence are listed in Table 1. These antibodies can be detected by different techniques, including indirect immunofluorescence, ${ }^{2}$ complement fixation test," radioimmunoassay," enzyme linked immunosorbent assay (ELISA), and

Address for correspondence: Prof F B Bianchi, Istituto di Clinica Medica II, Policlinico S. Orsola, Via Massarenti 9, I-40138 Bologna, Italy.

Received for publication 16 October 1987. double immunodiffusion. ${ }^{12}$ The most widely used method for screening purposes is immunofluorescence on cryostat sections of rat liver, kidney and stomach. Especially rat kidney permits distinction between the morphological patterns characteristic of M1, M2, and M4 (together or separately they give the same pattern), M3, M5, and M6, but does not provide information about the nature of the antigen(s) involved in the reaction. The overall prevalence of antimitochondrial antibody is around $0.5 \%$ in normal subjects, but it dramatically increases 
Table 1 Different specificities of anitmitochondrial antibodies and their occurrence

\begin{tabular}{|c|c|c|}
\hline & Occurence & Reference \\
\hline M1 & secondary syphilis & 1 \\
\hline M2 & primary biliary cirrhosis & 2 \\
\hline M3 & venocuran-induced pseudolupus & 3 \\
\hline M4 & $\begin{array}{l}\text { 'mixed form' of chronic cholestatic liver disease, } \\
\text { primary biliary cirrhosis }\end{array}$ & 4 \\
\hline M5 & $\begin{array}{l}\text { particular subgroup of systemic lupus } \\
\text { erythematosus }\end{array}$ & 5 \\
\hline M6 & iproniazid induced hepatitis & 6 \\
\hline M7 & cardiomyopathies & 7 \\
\hline M8 & primary biliary cirrhosis & 8 \\
\hline M9 & primary biliary cirrhosis, healthy subjects & 9 \\
\hline \multicolumn{3}{|c|}{ M-A primary biliary cirrhosis, } \\
\hline \multirow{2}{*}{\multicolumn{2}{|c|}{$\begin{array}{l}\text { M-B progressive systemic sclerosis } \\
\text { M-C }\end{array}$}} & 10 \\
\hline & & \\
\hline
\end{tabular}

up to $95-99 \%$ in patients with primary biliary cirrhosis, ${ }^{13}$ so that the M2 antibody is commonly regarded as the serological marker for this disease. It is well known, however, that antimitochondrial antibody with the same M2-M4 immunofluorescence pattern are also detected, though rarely, in the sera of patients without clinical or biochemical evidence of liver disorder. ${ }^{14}$ Recently a new technique, Western immunoblotting, has been applied to identify the mitochondrial peptides cross reacting with the antimitochondrial antibody of primary biliary cirrhosis sera. ${ }^{15-18}$

The aim of the present study is to compare the reactivities of the antimitochondrial antibody (with the M2-M4 immunofluorescence pattern) present in primary biliary cirrhosis and non-primary biliary cirrhosis sera, using immunoblotting and ELISA, in order to define if there are any differences in the antigen specificities of the antibodies detected by these methods in these two distinct groups of patients.

\section{Methods}

PATIENTS

SERA

Fifty six primary biliary cirrhosis sera with M2-M4 immunofluorescence antimitochondrial antibody reactivity were studied. The diagnosis of primary biliary cirrhosis was based on clinical, biochemical and histological data. ${ }^{19}$ Twenty seven patients were histologically classified in Stage I-II and 29 in Stage III-IV. Twenty one M2-M4 immunofluorescence antimitochondrial antibody positive sera from nonprimary biliary cirrhosis patients were also studied. These were from patients with cryptogenic chronic active hepatitis (three), connective tissue disorders (four), vitiligo (two), alopecia (one), Type I diabetes (one), hypothyroidism (one), Type II diabetes (two), Cushing syndrome (one), lung neoplasm (one), bronchial pneumonia (one), atherosclerosis (one), food allergy (one), hiatal hernia (one), and one healthy subject. None of the non-primary biliary cirrhosis patients, except the three chronic active hepatitis cases, showed any clinical or biochemical feature of liver damage. Three percutaneous liver biopsies from patients without evidence of liver disease (one vitiligo and two Type II diabetes) were carried out and histologically they were normal. As controls, we also studied 10 sera from healthy subjects without autoantibodies and 37 sera with a variety of non-organ and organ-specific autoantibodies: anti-nuclear antibody (five), liver kidney microsomal antibody (three), rheumatoid factor (10), human parietal cell antibody (four), islet cell antibody (five), thyroid microsomal (five), and thyroglobulin (five) antibodies.

\section{IMMUNOFLUORESCENCE STUDIES}

Antimitochondrial antibody as well as anti-nuclear antibody, liver kidney microsomal antibody, parietal cell antibody, and islet cell antibody were initially detected by the standard indirect immunofluorescence technique using cryostat sections from composite blocks of rat liver and kidney, human stomach and pancreas. For non-organ specific autoantibodies (antimitochondrial antibody, anti-nuclear antibody, liver kidney microsomal antibody), the screening dilution of the sera was 1:10, while for the organ specific ones (parietal cell antibody, islet cell antibody) the sera were tested undiluted. Antimitochondrial antibody were titrated by serial dilution to end point. Thyroglobulin, thyroid microsomal and rheumatoid factor were detected by commercial haemoagglutination kits.

\section{MITOCHONDRIAL ANTIGEN PREPARATION}

Mitochondria were first isolated from beef heart according to Beinerr ${ }^{20}$ and submitochondrial particles were then prepared according to Hanson and Smith. ${ }^{21}$ Both enriched fractions were washed three times with $10 \mathrm{mM}$ Tris- $\mathrm{HCl} \mathrm{pH} 7 \cdot 6,250 \mathrm{mM}$ sucrose, $0.5 \mathrm{mM}$ ethylendiaminetetra-acetic acid (EDTA) and stored in small aliquots at $-20^{\circ} \mathrm{C}$ until used. The protein content was determined according to Bradford. ${ }^{22}$

IMMUNOBLOTTING TECHNIQUE

Beef heart mitochondria were incubated for one hour at $37^{\circ} \mathrm{C}$ at a final concentration of $1 \mathrm{mg} / \mathrm{ml}$ in $125 \mathrm{mM}$ Tris- $\mathrm{HCl} \mathrm{pH} \mathrm{6 \cdot 8,} 2$ mM EDTA, $2 \%$ sodium dodecylsulphate, $50 \mathrm{mM}$ dithiothreitol. Then bromophenol blue was added (to a concentration of $0.001 \%$ ) and 
the samples were submitted to sodium dodecylsulphate polyacrylamide $(10 \%)$ gel electrophoresis according to Laemmli ${ }^{23}$ until the dye front had migrated $10 \mathrm{~cm}$. The molecular weight standards (SIGMA Chemicals, USA) for the determination of the molecular weights of the reacting mitochondrial peptides were treated as above. They were phosphorylase b $(94 \mathrm{kD})$, bovine serum albumin $(67 \mathrm{kD})$, ovalbumin $(43 \mathrm{kD})$, carbonic anhydrase $(30 \mathrm{kD})$, soyabean trypsin inhibitor $(20 \cdot 1 \mathrm{kD})$, and lactalbumin $(14.4 \mathrm{kD})$. The proteins in the gel were then transblotted onto a nitrocellulose sheet (pore size $0.45 \mu \mathrm{m}$, Sartorius, Western Germany) according to Towbin, and colleagues. ${ }^{24}$ The nitrocellulose was then either stained for proteins with amido black $0.1 \%$ in $25 \%$ isopropanol, $10 \%$ acetic acid and destained with the same solution without the dye, or used in the immunoblotting experiments. In this case the nitrocellulose was blocked with $3 \%$ dry milk powder in Tris buffered saline (TBS: $20 \mathrm{mM}$ Tris$\mathrm{HCl}, \mathrm{NaCl} 0.9 \% \mathrm{pH} 7.5$ ) for 1.5 hours at $37^{\circ} \mathrm{C}$ with gentle agitation. Then it was washed twice in TBS and incubated for one hour at $37^{\circ} \mathrm{C}$ with sera diluted $1: 100$ in TBS, $3 \%$ dry milk powder, $5 \%$ heat inactivated horse serum. The nitrocellulose was then washed five times for five minutes each with TBS and incubated with anti-human total immunoglobulins peroxidase conjugated antiserum (Miles Laboratories, USA) diluted 1:500 in TBS, 3\% dry milk powder, $5 \%$ heat inactivated horse serum for one hour at $37^{\circ} \mathrm{C}$. After five washings of five minutes each, the peroxidase was developed with $0.05 \%$ 4-chloro-1-naphtol (Bio-Rad Laboratories, USA) in TBS, $17 \%$ methanol, $0.015 \% \mathrm{H}_{2} \mathrm{O}_{2}$ for 30 minutes at room temperature.

\section{ELISA}

Beef heart submitochondrial particles were diluted to a concentration of $20 \mu \mathrm{g} / \mathrm{ml}$ in $0.06 \mathrm{M}$ carbonatebicarbonate buffer $\mathrm{pH} 9 \cdot 6$. The plates (Dynatech Immulon. USA) were coated with $100 \mu \mathrm{l}$ of the antigen per well by overnight incubation at $4^{\circ} \mathrm{C}$. The wells were washed twice with $0.15 \mathrm{M}$ phosphate buffered saline (PBS) pH 7.4 and blocked with $100 \mu \mathrm{l}$ PBS, $1 \%$ casein for one hour at $37^{\circ} \mathrm{C}$. After three washings with $0 \cdot 1 \%$ Tween 20 in PBS, $100 \mu \mathrm{l}$ of the sera diluted $1: 1000$ in PBS, $0.5 \%$ casein, $0 \cdot 05 \%$ Tween 20 were added to each well. All sera were tested in duplicate and appropriate blanks were included into each plate. After an incubation of two hours at $4^{\circ} \mathrm{C}$, the plates were washed five times with $0 \cdot 1 \%$ Tween 20 in PBS and $100 \mu \mathrm{l}$ anti-human total immunoglobulins peroxidase conjugated antiserum (Miles Laboratories, USA) diluted 1:500 in PBS, $0.5 \%$ casein, $0.05 \%$ Tween 20 were added to each well. After a two hour incubation at $4^{\circ} \mathrm{C}$ the plates were washed five times with PBS, $0 \cdot 1 \%$ Tween 20 . The peroxidase was developed by adding $100 \mu \mathrm{l}$ per well of $0.04 \%$ o-phenylene-diamine (SIGMA Chemicals, USA) in $0 \cdot 01 \mathrm{M}$ citrate-phosphate buffer $\mathrm{pH} 6 \cdot 3,0 \cdot 01 \% \mathrm{H}_{2} \mathrm{O}_{2}$. After 30 minutes incubation in the dark at room temperature, the reaction was stopped by the addition of $200 \mu \mathrm{l} 0.5 \mathrm{M}$ citric acid and the colour quantified by measuring the absorbance at $450 \mathrm{~nm}$ in a micro ELISA autoreader (M 600 Multiscan, Dynatech, USA). Seven sera from normal subjects with no detectable autoantibodies were included in each plate and their values were used to calculate a normal range (mean ( $3 \mathrm{SD})$ ). The positivity was expressed in times exceeding the upper limit of the normal range and the sera were considered strongly positive $(++)$ when their values were more than three-fold this limit and weakly positive $(+)$ if the values were between one and three times this limit. The intra and interassay variations were consistently less than $10 \%$.

STATISTICAL ANAIYSIS

Analysis was performed using the Wilcoxson's rank sum test and the Spearman's rank correlation test when appropriate.

\section{Results}

IMMUNOFIUORESCENCE STUDIES

The titres of M2-M4 immunofluorescence antimitochondrial antibody in primary biliary cirrhosis sera (median 1:1280, range 1:10-1:10240) were significantly higher $(p<0 \cdot 01)$ than in non-primary biliary cirrhosis sera (median 1:80, range 1:20-1:1280).

IMMUNOBLOTTING

Using beef heart mitochondria seven bands at molecular weights of $74 \mathrm{kD}, 58 \mathrm{kD}, 55 \mathrm{kD}, 52 \mathrm{kD}$, $51 \mathrm{kD}, 46 \mathrm{kD}$, and $43 \mathrm{kD}$ reacting with the antimitochondrial antibody positive sera were identified (Fig. 1). Seventy of $77(91 \%)$ antimitochondrial antibody positive sera $(100 \%$ in primary biliary cirrhosis and $71 \%$ in non-primary biliary cirrhosis group) reacted with one or more bands, while none of the 47 antimitochondrial antibody negative control sera (including 37 with different autoantibodies) showed any bands. Most of the positive sera reacted with more than one band on the nitrocellulose strip giving a composite pattern, and no correlation was found between the reaction of any one band and that of any other. The number of positive bands was generally greater with the sera showing high immunofluorescence titres. The $74 \mathrm{kD}$ protein was the most commonly detected $(84 \%$ and $57 \%$ of antimitochondrial antibody positive primary biliary cirrhosis and non-primary biliary cirrhosis sera, respectively). 


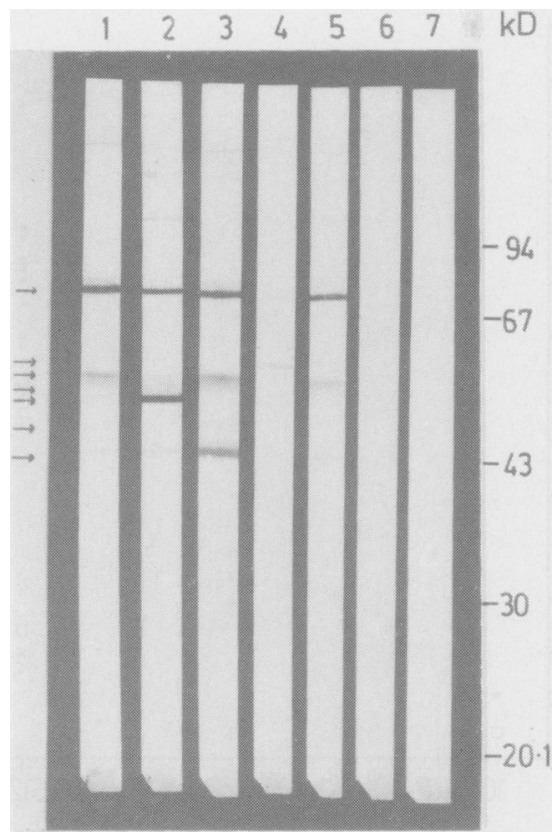

Fig. 1 Reactivity of M2-M4 immunofluorescence antimitochondrial antibody positive and negative sera in immunoblotting with beef heart mitochondria. The arrows indicate the relative motility of the 7 bands reacting with the positive sera, corresponding to $74 k D, 58 k D, 55 k D, 52 k D$, $5 I k D, 46 k D$, and $43 k D$ molecular weight. (Lanes 1-5: M2-M4 immunofluorescence antimitochondrial antibody positive sera; lanes 6 and 7: M2-M4 immunofluorescence antimitochondrial antibody negative sera).

Besides this one, three more bands, at $55 \mathrm{kD}, 52 \mathrm{kD}$, and $43 \mathrm{kD}$ molecular weight, were frequently found. The results are summarised in Table 2 . All primary biliary cirrhosis sera were positive in immunoblotting; the pattern was unrelated to the histological stage of the disease and, moreover, did not vary substantially from the pattern of non-primary biliary cirrhosis sera, when positive. All the nine primary biliary cirrhosis sera which failed to react with the 74 $\mathrm{kD}$ protein showed a positive band at $52 \mathrm{kD}$, associated with the $55 \mathrm{kD}$ reactivity in three sera. In the group of non-primary biliary cirrhosis patients, but with M2-M4 positive reaction by immuno-

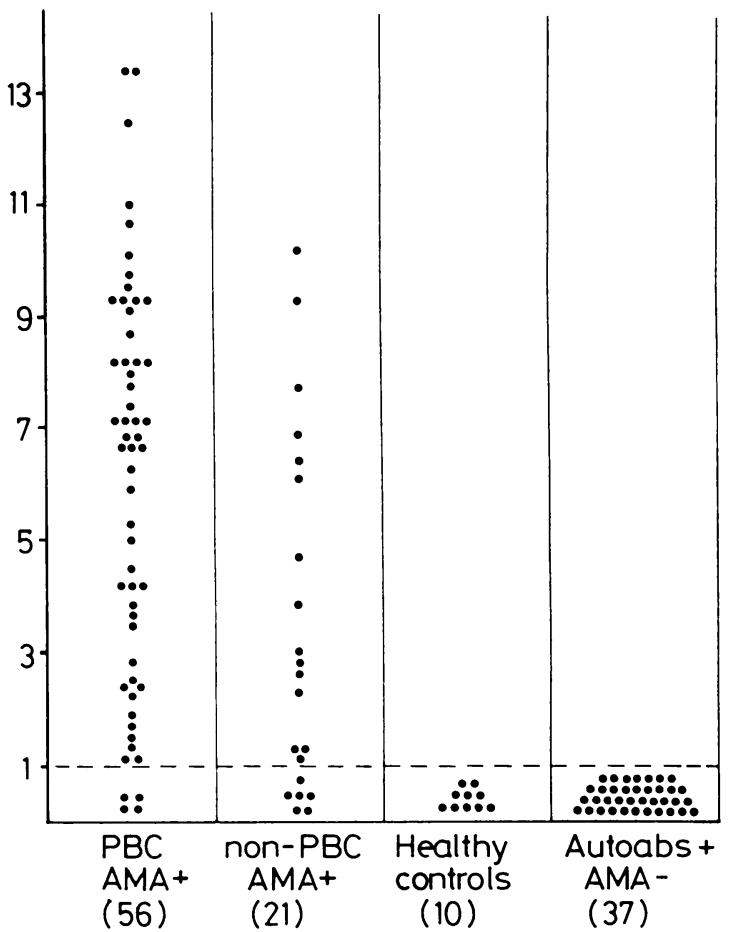

Fig. 2 Results of the ELISA test with beef heart submitochondrial particles. Results are expressed in times exceeding the upper limit of the normal range (see the text).

fluorescence, nine sera were negative for the $74 \mathrm{kD}$ band, including the three from chronic active hepatitis patients. Of these nine sera with undetectable 74 $\mathrm{kD}$ band, three showed a positive reaction at $52 \mathrm{kD}$ (associated with the $55 \mathrm{kD}$ band in two), while six were completely negative. Their immunofluorescence titres did not significantly differ from those of immunoblotting positive sera.

\section{EI.ISA}

Sixty seven (87\%) M2-M4 immunofluorescence antimitochondrial antibody positive sera were classified as positive by this test $(93 \%$ of primary biliary cirrhosis and $71 \%$ of non-primary biliary cirrhosis sera). None of the $47 \mathrm{M} 2-\mathrm{M} 4$ immunofluorescence antimitochondrial antibody negative sera reacted

Table 2 Frequencies of the bands detected by immunoblotting (IB) with beef heart mitochondria of primary biliary cirrhosis and non-primary biliary cirrhosis M2-M4 immunofluorescence antimitochondrial antibody positive sera

\begin{tabular}{|c|c|c|c|c|c|c|c|c|}
\hline & $74 k I)$ & $58 k I)$ & $55 k D$ & $52 k D$ & $51 k D$ & $46 k D$ & $43 k D$ & $I B-v e$ \\
\hline PBC AMA (56) & $47(84 \%)$ & $4(7 \%)$ & $43(77 \%)$ & $31(55 \%)$ & $20(36 \%)$ & $5(9 \%)$ & $31(55 \%)$ & - \\
\hline Non-PBC AMA (21) & $12(57 \%)$ & $1(5 \%)$ & $10(48 \%)$ & $9(43 \%)$ & $4(19 \%)$ & $1(5 \%)$ & $5(24 \%)$ & $6(29 \%)$ \\
\hline Total (77) & $59(77 \%)$ & $5(6 \%)$ & $53(69 \%)$ & $40(52 \%)$ & $24(31 \%)$ & $6(8 \%)$ & $36(47 \%)$ & $6(8 \%)$ \\
\hline
\end{tabular}


with beef heart submitochondrial particles. Results are summarised in Figure 2. The ELISA values of primary biliary cirrhosis positive antimitochondrial antibody sera (median 6.7 , range $0.5-13.4$ ) were significantly higher $(p<0.01)$ than those of nonprimary biliary cirrhosis patients with the same immunofluorescence specificity (median $2 \cdot 6$, range $0 \cdot 5-10 \cdot 2)$. A positive correlation was found between the ELISA results and the immunofluorescence titres $(\mathrm{p}<0 \cdot 05)$ (Fig. 3).

The relationship between immunoblotting and ELISA results is shown in Table 3. Grouping the sera on the basis of their ELISA values, $100 \%$ of ELISA strongly positive sera $(++)$ reacted with the $74 \mathrm{kD}$, $92 \%$ with the $55 \mathrm{kD}, 48 \%$ with the $51 \mathrm{kD}$, and $66 \%$ with the $43 \mathrm{kD}$ peptide, while only $47 \%, 24 \%, 0 \%$, and $17 \%$ of the ELISA weakly positive sera (+) reacted with the above four proteins, respectively. On the whole, ELISA and immunoblotting reactions, although carried out with different antigens (submitochondrial particles are known to contain mainly inner mitochondrial membranes), correlated for all the proteins detected by immunoblotting except for the $52 \mathrm{kD}$ peptide, which was apparently detected regardless of the ELISA results $(52 \%, 47 \%$, and $60 \%$ of ELISA,+++ , and negative sera, respectively). All the four ELISA negative primary biliary cirrhosis sera turned out to be positive for the $52 \mathrm{kD}$ protein in immunoblotting. The statistical significance of the correlation between ELISA and immunofluorescence titres increased to $p<0.001$ when considering only the sera reacting in immunoblotting with the $74 \mathrm{kD}$ protein (Fig. 3).

\section{Discussion}

Using Western immunoblotting analysis with beef heart mitochondrial proteins as antigenic substrate, the heterogeneity of anti-mitochondrial antibodies with M2-M4 immunofluorescence pattern is largely confirmed. In fact, we were able to detect seven different peptides of molecular weight (MW) $74 \mathrm{kD}$, $58 \mathrm{kD}, 55 \mathrm{kD}, 52 \mathrm{kD}, 51 \mathrm{kD}, 46 \mathrm{kD}$, and $43 \mathrm{kD}$ crossreacting with antimitochondrial antibody positive

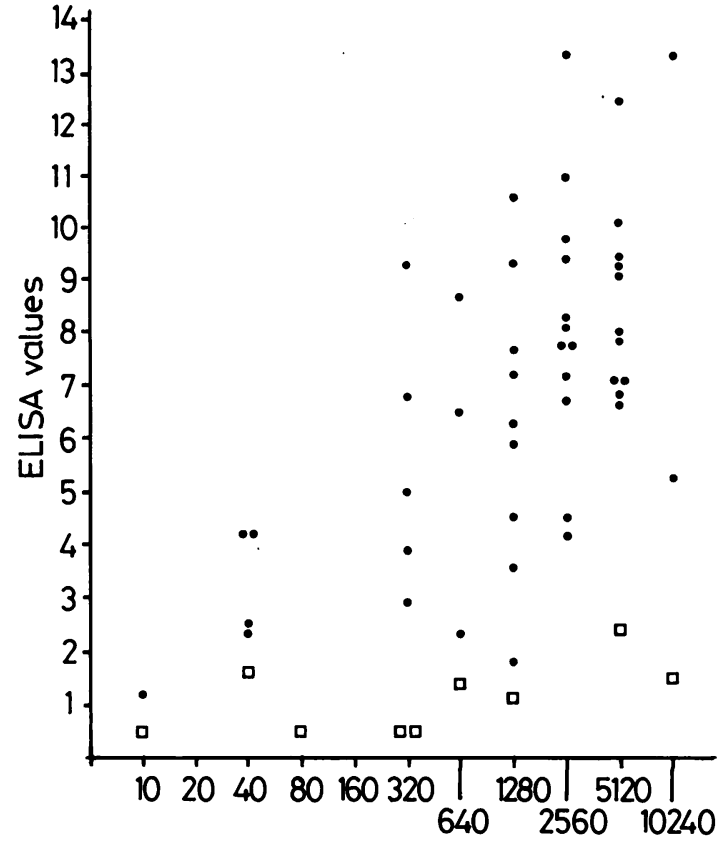

IFL titres

Fig. 3 Correlation between ELISA values (expressed in times exceeding the upper limit of the normal range-see the text) and immunofluorescence titres of the 56 M2-M4 immunofluorescence positive antimitochondrial antibody sera from primary biliary cirrhosis patients. $(74 k D+v e$ sera in immunoblotting; $\square 74 k D-v e$ but $52 k D+v e$ sera in immunoblotting.) $r=0.398 ; p<0.05$ (considering all 56 sera); $r=0.486 ; p<0.001$ (considering only the $74 k D+v e$ sera in immunoblotting.

sera. The consistent non-reactivity of all antimitochondrial antibody negative sera by immunofluorescence (including the 37 positive for other autoantibodies) indicates that what we have detected is antimitochondrial antibody specific. Recently immunoblotting has been applied by other Authors $^{15-18}$ in the identification of antimitochondrial antibody reactivities. In particular, Ishii et al ${ }^{18}$ have detected four proteins of the inner mitochondrial membrane reacting with primary biliary cirrhosis

Table 3 Comparison of immunoblotting (IB) and ELISA results of primary biliary cirrhosis and non-primary biliary cirrhosis M2-M4 immunofluorescence antimitochondrial antibody positive sera. (For definition of ELISA++, ELISA+, and ELISA - see the text)

\begin{tabular}{|c|c|c|c|c|c|c|c|c|c|c|}
\hline & & & $74 k D$ & $58 k D$ & $55 k D$ & $52 k D$ & $51 k D$ & $46 k D$ & $43 k D$ & $I B-v e$ \\
\hline \multirow[t]{3}{*}{ PBC AMA (56) } & ELISA ++ & $41(73 \%)$ & $41(100 \%)$ & $4(10 \%)$ & $38(93 \%)$ & $21(51 \%)$ & $20(49 \%)$ & $5(12 \%)$ & $30(73 \%)$ & - \\
\hline & ELISA+ & $11(20 \%)$ & $6(55 \%)$ & - & $4(36 \%)$ & $6(55 \%)$ & - & - & $1(9 \%)$ & - \\
\hline & ELISA- & $4(7 \%)$ & - & - & $1(25 \%)$ & $4(100 \%)$ & - & - & - & - \\
\hline \multirow[t]{3}{*}{ Non-PBC AMA (21) } & ELISA ++ & $9(42 \%)$ & $9(100 \%)$ & $1(11 \%)$ & $8(89 \%)$ & $5(56 \%)$ & $4(44 \%)$ & $1(11 \%)$ & $3(33 \%)$ & - \\
\hline & ELISA+ & $6(29 \%)$ & $2(33 \%)$ & - & - & $2(33 \%)$ & - & - & $2(33 \%)$ & $3(50 \%)$ \\
\hline & ELISA - & $6(29 \%)$ & $1(17 \%)$ & - & $2(33 \%)$ & $2(33 \%)$ & - & - & - & $3(50 \%)$ \\
\hline
\end{tabular}


sera. Considering both the complexity of the immunoblotting technique and of the molecular weight calculation, minor differences in molecular weight are to be expected from different laboratories. It is possible, however, that our $74,55,52$, and $43 \mathrm{kD}$ proteins correspond to the $70,54,51$, and 45 $\mathrm{kD}$ peptides described by Ishii $e t$ al. The fact that we have found seven different bands may be because of the use of whole beef heart mitochondria as antigens in our immunoblotting instead of submitochondrial particles, as done by Ishii et al. The absence of any correlation in the detection of any pair among the seven bands seems to exclude the possibility that some of these bands are derived from the proteolytic breakdown of peptides of higher molecular weight. Mitochondrial preparations do generate extra antigenic bands on storage, however, and these are accountable as proteolytic products of major antigenic bands of higher molecular weight. ${ }^{25}$ From a single immunofluorescence pattern it is thus possible to identify different bands by immunoblotting, with a positive correlation between the number of bands and the immunofluorescence titres obtained by antimitochondrial antibody.

Considering the anti-mitochondrial antibodies from primary biliary cirrhosis cases, $84 \%$ recognised the $74 \mathrm{kD}$ protein (often in association with the $52 \mathrm{kD}$ band), while the remaining $16 \%$ were negative for the $74 \mathrm{kD}$ band but invariably reacted with the $52 \mathrm{kD}$ one. In the ELISA test the intensity of the reactions correlated with all of the bands detected by immunoblotting except for that of $52 \mathrm{kD}$. Moreover, the correlation between the ELISA results and the immunofluorescence titres significantly increases (from $\mathrm{p}<0.05$ to $\mathrm{p}<0.001$ ) when sera reacting with this latter protein only were excluded. Thus, it is tempting to conclude that the $52 \mathrm{kD}$ peptide is the target of a mitochondrial specificity different from that at $74 \mathrm{kD} \mathrm{MW}$.

No clearcut conclusion is at present available on the relationship between antimitochondrial antibody specificities detected by complement fixation test, ELISA, immunodiffusion and immunoblotting. The presence in a crude preparation of $F_{1}$-ATPase (released from submitochondrial particles by chloroform treatment) has been taken as a characteristic of the M2 antigen. ${ }^{26}$ Because of its high prevalence of reactivity with immunofluorescence antimitochondrial antibody positive primary biliary cirrhosis sera and its presence in such a preparation of $F_{1}$-ATPase (data not shown), it is suggested that the $74 \mathrm{kD}$ peptide is the major antigenic component of M2. In the same time the hypothesis is advanced that the 52 $\mathrm{kD}$ reactivity may be associated with the M4 antimitochondrial antibody: in fact, the M4 antigen has been localised in the outer mitochondrial mem- brane ${ }^{4}$ and it is well known that submitochondrial particles (used in our ELISA as source of antigen) are mainly composed of inner mitochondrial membranes and may, at least in our preparation, have had very little outer membranes contamination. Moreover, the three immunofluorescence antimitochondrial antibody positive sera from chronic active hepatitis patients were negative for the $74 \mathrm{kD}$ band and two reacted with the $52 \mathrm{kD}$ one. There are two further clear distinctions between the $52 \mathrm{kD}$ peptide and the other reactivities. First, sera reacting only with the 52 $\mathrm{kD}$ peptide do not react against the chloroform released $F_{1}$-ATPase preparation (data not shown), second, the molecular weight of the ' $74 \mathrm{kD}$ family' may vary significantly depending upon the species from which mitochondria are prepared, ${ }^{25}$ whereas the molecular weight of the $52 \mathrm{kD}$ band is species independent (data not shown).

These data suggest the existence of an immunological heterogeneity within primary biliary cirrhosis patients, which can be divided in three different subgroups: one with $74 \mathrm{kD}(45 \%)$, one with $74 \mathrm{kD}$ and $52 \mathrm{kD}(39 \%)$, and one with $52 \mathrm{kD}(16 \%)$ reactive antimitochondrial antibody. Several lines of evidence indicate that primary biliary cirrhosis is indeed an heterogeneous entity, including its clinical spectrum ${ }^{27}$ and natural history. ${ }^{28}$ Grouping our cases on the basis of these different antimitochondrial antibody specificities, the association of the reactivities at $74 \mathrm{kD}$ and $52 \mathrm{kD}$ molecular weight seems to be more frequent in the advanced histological stages of the disease (Table 4), but this was not statistically significant. No other clinical or biochemical differences were found among these three subgroups. It might by hypothesised that the group with the M2 reactivity - the $74 \mathrm{kD}$ band by immunoblotting - will develop, in time, antibodies against the $52 \mathrm{kD}$ one, while there is another group, which lacks the M2 reactivity and reacts only with the $52 \mathrm{kD}$ band. No differences were found between this latter group and all of the other primary biliary cirrhosis patients, but it must be stressed that we do not have information about responses to treatment in these cases.

In the non-primary biliary cirrhosis group with M2-M4 immunofluorescence pattern the immunoblotting test, when positive, was similar to that given by primary biliary cirrhosis sera. It must be stressed

Table 4 Comparison of the antimitochondrial antibody specificities detected by immunoblotting with primary biliary cirrhosis sera in relation to the histological stage of the disease

\begin{tabular}{lrcr}
\hline & $74 k D$ & $74 k D+52 k D$ & $52 k D$ \\
\hline Stage I-II (27) & $16(59 \%)$ & $7(26 \%)$ & $4(15 \%)$ \\
Stage III-IV (29) & $9(31 \%)$ & $15(52 \%)$ & $5(17 \%)$ \\
\hline
\end{tabular}


that it is impossible to exclude the possibility that some subjects of this group had asymptomatic primary biliary cirrhosis without biochemical abnormalities. Six of these patients $(29 \%)$, however, were completely negative in immunoblotting. This does not seem to be related to the antibody titre; as the immunofluorescence titres were comparable in immunoblotting positive and negative sera. It seems reasonable to assume that the specificities of these six immunofluorescence antimitochondrial antibody positive sera are different from all of the others, which are immunoblotting reactive. The negativity of this test could be caused by a denaturing effect of the immunoblotting procedure on the antigen(s). The clinical significance of antimitochondrial antibody positivity in patients without evidence of a liver disorder $^{1314}$ is, at present, controversial. In this context, it seems relevant that six of our 21 antimitochondrial antibody positive non-primary biliary cirrhosis patients had an antibody which, although having the same immunofluorescence pattern, was actually different from the one present in primary biliary cirrhosis. On the other hand, the hypothesis that non-primary biliary cirrhosis patients with an immunoblotting pattern of positivity similar to that of primary biliary cirrhosis will eventually develop an overt disease can be tested only in prospective studies.

From the present data it can be concluded that ELISA is less sensitive than immunoblotting, although equally specific, for the detection of M2-M4 immunofluorescence antimitochondrial antibody. The lower sensitivity is in part due to the fact that submitochondrial particles seem to be poor in the antigens cross-reacting with the $52 \mathrm{kD}$ peptide. On the other hand the immunoblotting test increases the nosological specificity of the sensitive immunofluorescence test for the diagnosis of primary biliary cirrhosis because it is able to exclude immunofluorescence positive sera without immunoblotting reactivities, and to discriminate, among immunofluorescence positive sera, according to different immunoblotting patterns.

It is well known that there is a partial clinical, and sometimes even histological, overlap between primary biliary cirrhosis and cases of chronic liver disease with a cholestastic pattern which are antimitochondrial antibody positive with the M2-M4 immunofluorescence pattern. This latter group of patients is reported to respond to steroid therapy. ${ }^{29}$ Further investigations are needed to assess whether the different sensitivities to treatment can be related to the diversity of antimitochondrial antibody specificities.

Marco Fusconi was recipient of a grant from Terme di
Chianciano S.p.A., Chianciano Terme, Italy. This work was supported by CNR grant $n$ 86.00501.04. We gratefully acknowledge the Wellcome Trust for its financial support.

\section{References}

1 Wright DJM, Doniach D, Lessof MH, Turk JL, Grimble AS, Catterall RD. New antibody in early syphilis. Lancet 1970; i: 740-4.

2 Walker JG, Doniach D, Roitt IM, Sherlock S. Serological tests in diagnosis of primary biliary cirrhosis. Lancet 1965; i: 827-31.

3 Sayers TY, Binder T, Berg PA. Heterogeneity of antimitochondrial antibodies: characterization and separation of the antigen associated with the pseudolupus erythematosus syndrome. Clin Exp Immunol 1979; 37: 68-75.

4 Berg PA, Wiedmann KH, Sayers T, Klöppel G. Serological classification of chronic cholestatic liver disease by the use of two different types of antimitochondrial antibodies. Lancet 1980; ii: 1329-32.

5 Labro MT, Andrieu MC, Weber M, Homberg JC. A new pattern of non-organ and non-species-specific antiorganelle antibody detected by immunofluorescence: the mitochondrial antibody number 5. Clin Exp Immunol 1978; 31: 357-66.

6 Homberg JC, Stelly N, Adreis I, Abuaf N, Saadoun F, Andre JF. A new antimitochondrial antibody (antiM6) in iproniazid-induced hepatitis. Clin Exp Immunol 1982; 47: 93-102.

7 Klein R, Maisch B, Kochsiek K, Berg PA. Demonstration of organ specific antibodies against heart mitochondria (anti M7) in sera from patients with some forms of heart disease. Clin Exp Immunol 1985; 58: 283-92.

8 Weber $\mathrm{P}$, Brenner J, Stechemesser E, et al. Characterization and clinical relevance of a new complementfixing antibody - anti-M8 - in patients with primary biliary cirrhosis. Hepatology 1986; 6: 553-9.

9 Berg PA, Klein R, Linderborn-Fotinos J. Antimitochondrial antibodies in primary biliary cirrhosis. $J$ Hepatol 1986; 2: 123-31.

10 Gupta RC, Seibold JR, Krishnan MR, Steigerwald JC. Precipitating antibodies to mitochondrial proteins in progressive systemic sclerosis. Clin Exp Immunol 1984; 58: $68-76$.

11 Manns M, Meyer zum Büschenfelde KH. A mitochondrial antigen-antibody system in cholestatic liver disease detected by radioimmunoassay. Hepatology 1982; 2: 1-7.

12 Gupta RC. Specificities and characteristics of mitochondrial protein antigens assessed by enzyme linked immunosorbent assay for antimitochondrial antibodies. Relationship to immunofluorescent and precipitating antibodies. Clin Exp Immunol 1985; 59: 604-12.

13 Munoz LE, Thomas HC, Scheuer PJ, Doniach D, Sherlock S. Is mitochondrial antibody diagnostic of primary biliary cirrhosis? Gut 1981; 22: 136-40.

14 Triger DR, Charlton CAC, Ward AM. What does antimitochondrial antibody mean? Gut 1982; 23: 814-8. 
15 Baum H, Palmer C. The PBC-specific antigen. Mol Aspects Med 1985; 8: 201-34.

16 Frazer IH, Mackay IR, Jordan TW, Wittingham S, Marzuky S. Reactivity of anti-mitochondrial autoantibodies in primary biliary cirrhosis: definition of two novel mitochondrial polypeptide autoantigens. $J$ Immunol 1985; 135: 1739-45.

17 Lindenborn-Fotinos J, Baum H, Berg PA. Mitochondrial antibodies in primary biliary cirrhosis: species and nonspecies specific determinants of M2 antigen. Hepatology 1985; 5: 763-9.

18 Ishii H, Saifuku K, Namihisa T. Reactivities and clinical relevance of antimitochondrial antibodies to four mitochondrial inner membrane proteins in sera of patients with primary biliary cirrhosis. Hepatology 1987; 7: 134-6.

19 Leevy CM, Popper H, Sherlock S. Diseases of the liver and biliary tract. Standardization of nomenclature, diagnostic criteria and diagnostic methodology. Fogarty International Center Proc 1976; 22: 76-725.

20 Beinert H. In: Umbreit WW, Burris RH, Stauffner JF, eds. Manometric techniques. Minneapolis: Burgess Publ Co, 1984: 124-9.

21 Hanson M, Smith AL. Studies on mechanism of oxidative phosphorilation. VII. Preparation of a submitochondrial particles (ETP-H) which is capable of fully coupled oxidative phosphorilation. Biochem Biophys Acta 1964; 81: 214-22.
22 Bradford MM. A rapid and sensitive method for the detection of protein utilizing the principle of protein dye binding. Anal Biochem 1975; 72: 248-54.

23 Laemmli U. Cleavage of structural proteins during the assembly of the head of bacteriophage T4. Nature 1970; 277: $680-5$.

24 Towbin H, Staehelin T, Gordon J. Electrophoretic transfer of proteins from polyacrylamide gels to nitrocellulose sheets: procedure and some applications. Proc Natl Acad Sci USA 1979; 76: 4350-4.

25 Ghadiminejad I, Baum $H$. Reaction pattern of antimitochondrial antibody of primary biliary cirrhosis (PBC) is species-specific but non organ-specific. $J$ Bioenerg Biomembr 1987; 19: 245-59.

26 Baum H, Berg PA. The complex nature of mitochondrial antibodies and their relation to primary biliary cirrhosis. Semin Liver Dis 1981; 1: 309-21.

27 Bernstein RM, Neuberger JM, Bunn CC, Callender ME, Hughes GRV, Williams R. Diversity of autoantibodies in primary biliary cirrhosis and chronic active hepatitis. Clin Exp Immunol 1984; 55: 553-60.

28 Beswick RD, Boyer JL. Primary biliary cirrhosis. Hepatology 1984; 4: suppl 1: 29S-35S.

29 Kenny RP, Czaja AJ, Ludwig J, Dickson ER. Frequency and significance of antimitochondrial antibodies in severe chronic active hepatitis. Dig $\mathrm{Dis} \mathrm{Sci}$ 1986; 31: 705-11. 